\title{
Can mud (silt and clay) concentration be used to predict soil organic carbon content within seagrass ecosystems?
}

\author{
Oscar Serrano ${ }^{1,2}$, Paul S. Lavery ${ }^{1,3}$, Carlos M. Duarte ${ }^{4}$, Gary A. Kendrick ${ }^{2,5}$, Antoni Calafat ${ }^{6}$, Paul H. York ${ }^{7}$, \\ Andy Steven $^{8}$, and Peter I. Macreadie ${ }^{9,10}$ \\ ${ }^{1}$ School of Natural Sciences \& Centre for Marine Ecosystems Research, Faculty of Health, Engineering and Science, \\ Edith Cowan University, Joondalup, 6027, Western Australia \\ ${ }^{2}$ The UWA Oceans Institute, The University of Western Australia, Crawley, WA, Australia \\ ${ }^{3}$ Centro de Estudios Avanzados de Blanes, Consejo Superior de Investigaciones Científicas, Blanes, 17300, Spain \\ ${ }^{4}$ King Abdullah University of Science and Technology (KAUST), Red Sea Research Center (RSRC), Thuwal, 23955-6900, \\ Saudi Arabia \\ ${ }^{5}$ The School of Plant Biology, The University of Western Australia, Crawley, WA, Australia \\ ${ }^{6}$ GRC Geociències Marines, Departament de Dinàmica de la Terra i de l'Oceà, Universitat de Barcelona, Barcelona, Spain \\ ${ }^{7}$ Centre for Tropical Water and Aquatic Ecosystem Research (TropWATER), James Cook University, \\ Cairns QLD 4870, Australia \\ ${ }^{8}$ CSIRO, EcoSciences Precinct - Dutton Park 41 Boggo Road Dutton Park QLD 4102, Australia \\ ${ }^{9}$ Centre for Integrative Ecology, School of Life and Environmental Sciences, Deakin University, Burwood, \\ Victoria 3125, Australia \\ ${ }^{10}$ Plant Functional Biology and Climate Change Cluster, University of Technology Sydney, Broadway, \\ New South Wales 2007, Australia
}

Correspondence to: Oscar Serrano (o.serranogras@ecu.edu.au)

Received: 24 November 2015 - Published in Biogeosciences Discuss.: 18 January 2016

Revised: 5 August 2016 - Accepted: 10 August 2016 - Published: 7 September 2016

\begin{abstract}
The emerging field of blue carbon science is seeking cost-effective ways to estimate the organic carbon content of soils that are bound by coastal vegetated ecosystems. Organic carbon $\left(\mathrm{C}_{\text {org }}\right)$ content in terrestrial soils and marine sediments has been correlated with mud content (i.e., silt and clay, particle sizes $<63 \mu \mathrm{m}$ ), however, empirical tests of this theory are lacking for coastal vegetated ecosystems. Here, we compiled data $(n=1345)$ on the relationship between $\mathrm{C}_{\text {org }}$ and mud contents in seagrass ecosystems ( 79 cores) and adjacent bare sediments ( 21 cores) to address whether mud can be used to predict soil $\mathrm{C}_{\text {org }}$ content. We also combined these data with the $\delta^{13} \mathrm{C}$ signatures of the soil $\mathrm{C}_{\text {org }}$ to understand the sources of $\mathrm{C}_{\text {org }}$ stores. The results showed that mud is positively correlated with soil $\mathrm{C}_{\text {org }}$ content only when the contribution of seagrass-derived $\mathrm{C}_{\text {org }}$ to the sedimentary $\mathrm{C}_{\text {org }}$ pool is relatively low, such as in small and fast-growing meadows of the genera Zostera, Halodule and Halophila, and in bare sediments adjacent to seagrass ecosystems. In
\end{abstract}

large and long-living seagrass meadows of the genera Posidonia and Amphibolis there was a lack of, or poor relationship between mud and soil $\mathrm{C}_{\text {org }}$ content, related to a higher contribution of seagrass-derived $\mathrm{C}_{\text {org }}$ to the sedimentary $\mathrm{C}_{\text {org }}$ pool in these meadows. The relatively high soil $\mathrm{C}_{\text {org }}$ contents with relatively low mud contents (e.g., mud- $\mathrm{C}_{\text {org }}$ saturation) in bare sediments and Zostera, Halodule and Halophila meadows was related to significant allochthonous inputs of terrestrial organic matter, while higher contribution of seagrass detritus in Amphibolis and Posidonia meadows disrupted the correlation expected between soil $\mathrm{C}_{\text {org }}$ and mud contents. This study shows that mud is not a universal proxy for blue carbon content in seagrass ecosystems, and therefore should not be applied generally across all seagrass habitats. Mud content can only be used as a proxy to estimate soil $\mathrm{C}_{\text {org }}$ content for scaling up purposes when opportunistic and/or low biomass seagrass species (i.e., Zostera, Halodule and Halophila) are present (explaining 34 to $91 \%$ of vari- 
ability), and in bare sediments (explaining $78 \%$ of the variability). The results obtained could enable robust scaling up exercises at a low cost as part of blue carbon stock assessments.

\section{Introduction}

The sedimentary organic carbon $\left(\mathrm{C}_{\text {org }}\right)$ stores of seagrass meadows - often referred to as "blue carbon" - can vary among seagrass species and habitats, with reports of up to 18-fold differences (Lavery et al., 2013). Ambiguity remains in the relative importance of the depositional environment and species characteristics contributing to this variability. Seagrasses occur in a variety of coastal habitats, ranging from highly depositional environments to highly exposed and erosional habitats (Carruthers et al., 2007). Since seagrass species differ in their biomass and canopy structure, and occur in a variety of habitat types, this raises the question of whether mud content can be used to predict $\mathrm{C}_{\text {org }}$ content within coastal sediments, or whether the species composition will significantly influence the soil $\mathrm{C}_{\text {org }}$ stores independently of the geomorphological nature of the habitat.

Geomorphological settings (i.e., topography and hydrology), soil characteristics (e.g., mineralogy and texture) and biological features (e.g., primary production and remineralization rates) control soil $\mathrm{C}_{\text {org }}$ storage in terrestrial ecosystems (Amundson, 2001; De Deyn et al., 2008; Jonsson and Wardle, 2009) and in mangrove and tidal salt marshes (Donato et al., 2011; Adame et al., 2013; Ouyang and Lee, 2014). While it is clear that habitat interactions have a large influence on stores of soil $\mathrm{C}_{\mathrm{org}}$, our understanding of the factors regulating this influence in seagrass meadows is limited (Nellemann et al., 2009; Duarte et al., 2010; Serrano et al., 2014).

The accumulation of $\mathrm{C}_{\text {org }}$ in seagrass meadows results from several processes: accretion (autochthonous plant and epiphyte production, and trapping of allochthonous $\mathrm{C}_{\mathrm{org}}$; Kennedy et al., 2010), erosion (e.g., export; Romero and Pergent, 1992; Hyndes et al., 2014) and decomposition (Mateo et al., 1997). Previous studies demonstrate that both autochthonous (e.g., plant detritus and epiphytes) and allochthonous (e.g., macroalgae, seston and terrestrial matter) sources contribute to the $\mathrm{C}_{\text {org }}$ pool in seagrass soils (Kennedy et al., 2010; Watanabe and Kuwae, 2015). Plant net primary productivity is a key factor controlling the amount of $\mathrm{C}_{\mathrm{org}}$ potentially available for sequestration in seagrass ecosystems (Serrano et al., 2014), but the depositional environment is an important factor controlling $\mathrm{C}_{\text {org }}$ storage in coastal habitats (De Falco et al., 2004; Lavery et al., 2013).

Previous studies have shown a large variation in $\mathrm{C}_{\text {org }}$ stores among morphologically different seagrass species (Lavery et al., 2013; Rozaimi et al., 2013). Also, that $\mathrm{C}_{\text {org }}$ accumulates more in estuaries compared to coastal ocean envi- ronments (estimated at 81 and $45 \mathrm{Tg} \mathrm{C}_{\mathrm{org}} \mathrm{yr}^{-1}$, respectively; Nellemann et al., 2009). This is due largely to estuaries being highly depositional environments, receiving fine-grained particles from terrestrial and coastal ecosystems which enhance $\mathrm{C}_{\text {org }}$ accumulation (i.e., silt and clay sediments retain more $\mathrm{C}_{\text {org }}$ compared to sands; Keil and Hedges, 1993; Burdige, 2007) and preservation (i.e., reducing redox potentials and remineralization rates; Hedges and Keil, 1995; Dauwe et al., 2001; Burdige, 2007; Pedersen et al., 2011). The inputs of seagrass-derived $\mathrm{C}_{\mathrm{org}}$ in the sedimentary pool could break the linear relationship among mud (i.e., silt and clay particles) and $\mathrm{C}_{\text {org }}$ contents typically found in terrestrial (Nichols, 1984; McGrath and Zhang, 2003) and marine sedimentary environments (Bergamaschi et al., 1997; De Falco et al., 2004). However, the amount of $C_{\text {org }}$ that can be associated with mud particles is limited (Hassink, 1997), which could lead to a poor relationship between mud and soil $\mathrm{C}_{\text {org }}$ contents. Also, other factors found to play a key role in controlling soil $\mathrm{C}_{\text {org }}$ accumulation in terrestrial and coastal ecosystems, such as chemical stabilization of organic matter (Percival et al., 1999; Burdige, 2007), carbon in microbial biomass (Sparling, 1992; Danovaro et al., 1995), and soil temperature (Pedersen et al., 2011), could also influence $\mathrm{C}_{\text {org }}$ storage in seagrass meadows.

A significant relationship between mud and $\mathrm{C}_{\text {org }}$ contents would allow mud to be used as a proxy for $\mathrm{C}_{\text {org }}$ content, thereby enabling robust scaling up exercises at a low cost as part of blue carbon stock assessments. Furthermore, since most countries have conducted geological surveys within the coastal zone to determine sediment grain size, a strong, positive relationship between mud and $\mathrm{C}_{\text {org }}$ contents would allow the development of geomorphology models to predict blue carbon content within seagrass meadows, dramatically improving global estimates of blue carbon storage. The purpose of this study was therefore to test for relationships between $\mathrm{C}_{\text {org }}$ and mud contents within seagrass ecosystems and adjacent bare sediments.

\section{Material and methods}

Data were compiled from a number of published and unpublished studies from Australia and Spain, in seagrass meadows across diverse habitats (Table 1). The study sites encompass monospecific and/or mixed meadows from a variety of temperate and tropical seagrass species of the genera Posidonia, Amphibolis, Zostera, Halophila and Halodule, and adjacent bare sediments, while including a variety of depositional environments (from estuarine to exposed coastal areas encompassing different water depths, from intertidal to the deep limit of seagrass distribution; Table 1). Data from 100 cores (79 from seagrass meadows and 21 from bare sediments) on sediment grain size, organic carbon $\left(\mathrm{C}_{\text {org }}\right)$ content and stable carbon isotope signatures of the $\mathrm{C}_{\mathrm{org}}\left(\delta^{13} \mathrm{C}\right)$ were explored in this study $(N=1345)$. 
Table 1. Data on soil organic carbon and mud contents, and stable carbon isotope from coastal soils were gathered from a variety of seagrass meadows (and also from adjacent bare sediments) and habitat types.

\begin{tabular}{|c|c|c|c|c|c|c|}
\hline Species & Study site & Geomorphology & $\begin{array}{l}\text { Number } \\
\text { of cores }\end{array}$ & $\begin{array}{r}\text { Number } \\
\text { of samples }\end{array}$ & $\begin{array}{l}\text { Core depth } \\
(\mathrm{cm})\end{array}$ & $\begin{array}{l}\text { Water depth } \\
\text { (m) }\end{array}$ \\
\hline Amphibolis (mixed spp.) & Rottnest Island, WA, Australia & Coastal & 2 & 68 & $0-120$ & 2 \\
\hline Amphibolis antarctica & Shark Bay, WA, Australia & Coastal & 2 & 63 & $0-200$ & $2-3$ \\
\hline Amphibolis griffithii & Jurien Bay, WA, Australia & Coastal & 2 & 41 & $0-70$ & 4 \\
\hline Posidonia australis & Oyster Harbour, WA, Australia & Estuarine & 3 & 31 & $0-120$ & 2 \\
\hline \multirow[t]{3}{*}{ Posidonia sinuosa } & Frenchman's Bay, WA, Australia & Coastal & 4 & 100 & $0-80$ & $2-8$ \\
\hline & Cockburn Sound, WA, Australia & Coastal & 3 & 50 & $0-30$ & 6 \\
\hline & Garden Island, WA, Australia & Coastal & 5 & 147 & $0-120$ & $2-8$ \\
\hline \multirow[t]{2}{*}{ Posidonia oceanica } & Portlligat, Spain & Coastal & 1 & 192 & 475 & 3 \\
\hline & Balearic Islands, Spain & Coastal & 6 & 25 & $0-270$ & 3 \\
\hline \multirow{4}{*}{ Halophila ovalis } & Swan River, WA, Australia & Estuarine & 1 & 5 & $0-70$ & 2 \\
\hline & Leschenault Inlet, WA, Australia & Estuarine & 1 & 8 & $0-120$ & 1 \\
\hline & Harvey Inlet, WA, Australia & Estuarine & 1 & 5 & $0-20$ & 2 \\
\hline & Gladstone, QLD, Australia & Estuarine & 2 & 2 & $0-10$ & intertidal \\
\hline \multirow[t]{3}{*}{ Zostera muelleri } & Fagans Bay, NSW, Australia & Estuarine & 2 & 20 & $0-10$ & intertidal \\
\hline & Gladstone, QLD, Australia & Estuarine & 23 & 23 & $0-10$ & intertidal \\
\hline & Tuggerah Lakes, NSW, Australia & Estuarine & 2 & 64 & $0-400$ & 3 \\
\hline \multirow[t]{4}{*}{ Bare } & Cockburn Sound, WA, Australia & Coastal & 10 & 131 & $0-30$ & $2-9$ \\
\hline & Garden Island, WA, Australia & Coastal & 1 & 16 & $0-30$ & 4 \\
\hline & Oyster Harbour, WA, Australia & Estuarine & 1 & 26 & $0-110$ & 3 \\
\hline & Gladstone, QLD, Australia & Estuarine & 9 & 9 & $0-10$ & intertidal \\
\hline
\end{tabular}

Sediment cores were sampled by means of percussion and rotation, or vibrocoring (ranging from 10 to $475 \mathrm{~cm}$ long). The core barrels consisted of PVC or aluminium pipes (50 to $90 \mathrm{~mm}$ inside diameter) with sharpened ends to cut fibrous material and minimize core shortening (compression) during coring (Serrano et al., 2012, 2014). All cores were sealed at both ends, transported vertically to the laboratory and stored at $5^{\circ} \mathrm{C}$ before processing.

The cores were sliced at regular intervals, each slice and/or sample was weighed before and after oven drying to constant weight at $70^{\circ} \mathrm{C}$ (DW), and subsequently sub-divided for analysis. The $\mathrm{C}_{\text {org }}$ elemental and isotopic composition of the organic matter was measured in milled subsamples from several slices along the cores. The sediment core sub-samples were acidified with $1 \mathrm{M} \mathrm{HCl}$, centrifuged (3500 RPM; 5 min) and the supernatant with acid residues was removed using a pipette, then washed in deionized water, centrifuged again and the supernatant removed. The residual samples were redried $\left(70^{\circ} \mathrm{C}\right)$ before carbon elemental and isotopic analyses. The samples were encapsulated and the organic carbon elemental and isotopic composition was analyzed using an elemental analyzer interfaced with an isotope ratio mass spec- trometer. Percentage $\mathrm{C}_{\text {org }}$ was calculated for the bulk (preacidified) samples. Carbon isotope ratios are expressed as $\delta$ values in parts per thousand (\%o) relative to VPDB (Vienna Pee Dee Belemnite). For sediment grain size analysis, a Coulter LS230 laser-diffraction particle analyzer was used following digestion of the samples with $10 \%$ hydrogen peroxide. The mud content in the sediments $(<63 \mu \mathrm{m})$ was determined, and expressed as a percentage of the bulk sample.

Pearson correlation analysis was used to test for significant relationships among $\mathrm{C}_{\text {org }}$ and mud contents, and $\mathrm{C}_{\mathrm{org}}$ and $\delta^{13} \mathrm{C}$ signatures. Correlations between the variables studied were tested among seagrass species (nine categories) and bare sediments, seagrass genera (four categories), habitat geomorphology (coastal and estuarine habitats) and soil depth (in 1 to 10 and 11 to $110 \mathrm{~cm}$ thick deposits).

\section{Results}

The soil organic carbon $\left(\mathrm{C}_{\text {org }}\right)$ and mud contents varied within the seagrass meadows and bare sediments studied in Australia and Spain. The soil $\mathrm{C}_{\text {org }}$ and mud contents were higher in seagrass meadows (average $\pm \mathrm{SE}, 1.5 \pm 0.2 \%$ 
Table 2. Average $\pm \mathrm{SE}$ organic carbon $\left(\mathrm{C}_{\text {org }}\right)$ content (in $\left.\%\right), \delta^{13} \mathrm{C}$ signatures and mud content in all habitats and soil depths studied. (a) Descriptive statistics based on species identity. (b) Descriptive statistics based on habitat geomorphology (estuarine vs. coastal environments). $N$, number of samples.

\begin{tabular}{|c|c|c|c|c|c|c|c|c|c|}
\hline \multicolumn{10}{|l|}{ (a) } \\
\hline \multirow{2}{*}{$\begin{array}{l}\text { Habitat } \\
\text { (species) }\end{array}$} & \multicolumn{3}{|c|}{ Organic carbon $(\%)$} & \multicolumn{3}{|c|}{$\delta^{13} \mathrm{C}(\% \circ)$} & \multicolumn{3}{|c|}{ Mud (\%) } \\
\hline & $N$ & Mean & SE & $N$ & Mean & SE & $N$ & Mean & $\mathrm{SE}$ \\
\hline Posidonia oceanica & 217 & 3.91 & 0.35 & 217 & -14.92 & 0.08 & 217 & 11.73 & 0.53 \\
\hline Posidonia australis & 248 & 1.87 & 0.08 & 244 & -15.79 & 0.24 & 248 & 11.79 & 0.68 \\
\hline Posidonia sinuosa & 297 & 0.80 & 0.04 & 291 & -14.08 & 0.16 & 297 & 2.59 & 0.18 \\
\hline Amphibolis (mixed spp.) & 106 & 1.41 & 0.11 & 106 & -15.20 & 0.23 & 106 & 4.75 & 0.33 \\
\hline Amphibolis antarctica & 63 & 0.99 & 0.06 & 62 & -14.62 & 0.24 & 63 & 6.64 & 0.44 \\
\hline Amphibolis griffithii & 41 & 0.85 & 0.07 & 36 & -15.83 & 0.56 & 41 & 5.44 & 0.29 \\
\hline Halodule uninervis & 45 & 0.78 & 0.12 & 45 & -19.86 & 0.53 & 45 & 17.68 & 3.04 \\
\hline Zostera muelleri & 107 & 1.10 & 0.07 & 43 & -20.02 & 0.30 & 107 & 31.68 & 2.59 \\
\hline Halophila decipiens & 2 & 1.87 & 0.51 & 2 & -25.60 & 0.31 & 2 & 65.99 & 9.62 \\
\hline Halophila ovalis & 37 & 0.97 & 0.23 & 37 & -17.22 & 0.44 & 37 & 24.09 & 6.23 \\
\hline Bare & 182 & 0.59 & 0.08 & 182 & -17.25 & 0.24 & 182 & 10.83 & 1.20 \\
\hline Grand Total & 1345 & 1.56 & 0.07 & 1265 & -16.18 & 0.10 & 1345 & 10.83 & 0.43 \\
\hline \multicolumn{10}{|l|}{ (b) } \\
\hline \multirow{2}{*}{$\begin{array}{l}\text { Habitat } \\
\text { (geomorphology) }\end{array}$} & \multicolumn{3}{|c|}{ Organic carbon $(\%)$} & \multicolumn{3}{|c|}{$\delta^{13} \mathrm{C}(\% \circ)$} & \multicolumn{3}{|c|}{ Mud (\%) } \\
\hline & $N$ & Mean & SE & $N$ & Mean & SE & $N$ & Mean & $\mathrm{SE}$ \\
\hline Coastal & 1026 & 1.59 & 0.09 & 1014 & -15.70 & 0.10 & 1026 & 6.85 & 0.24 \\
\hline Estuarine & 319 & 1.44 & 0.07 & 251 & -18.10 & 0.24 & 319 & 23.62 & 1.41 \\
\hline
\end{tabular}

and $18 \pm 2.4 \%$, respectively) compared to bare sediments $(0.6 \pm 0.1 \%$ and $10.8 \pm 1.2 \%$, respectively; Table 2$)$. On average, seagrass meadows of the genera Amphibolis and Posidonia contained higher soil $\mathrm{C}_{\text {org }}(1.6 \pm 0.1 \%)$ and lower mud $(7.2 \pm 0.4)$ than meadows of Halophila, Halodule and Zostera $(1.2 \pm 0.2 \%$ and $34.9 \pm 5.4 \%$, respectively; Table 2). Overall, carbon isotopic ratios from sedimentary organic matter $\left(\delta^{13} \mathrm{C}\right)$ were similar between seagrass soils and bare sediments $(-17.6 \pm 0.3 \%$ and $-17.3 \pm 0.2 \%$, respectively). The $\mathrm{C}_{\mathrm{org}}$ in soils from Posidonia and Amphibolis meadows were ${ }^{13} \mathrm{C}$-enriched $(-15.5 \pm 0.3 \%$ ) compared with seagrass soils from Halophila, Halodule and Zostera meadows $(-20.7 \pm 0.4 \%$; Table 2$)$. The $\mathrm{C}_{\text {org }}$ content in soils from estuarine and coastal habitats were similar, while mud content in estuarine sediments was higher and $\delta^{13} \mathrm{C}$ values depleted when compared to coastal habitats (Table 2).

The relationships between the variables studied (i.e., $\% \mathrm{C}_{\text {org }}, \%$ mud, and $\delta^{13} \mathrm{C}$ signatures of sedimentary $\mathrm{C}_{\text {org }}$ ) among different species and habitat geomorphologies, and among different soil depths were explored in Figs. 1 to 3, and Table 3. When accounting for the whole data set (up to $475 \mathrm{~cm}$ long cores), the $\mathrm{C}_{\text {org }}$ content increased with increasing mud content in bare sediments $\left(R^{2}=0.78\right)$ and at species level, except for Posidonia oceanica (i.e., $\mathrm{C}_{\text {org }}$ content decreased with increasing mud content; $\left.R^{2}=0.15\right)$ and $A m$ phibolis griffithii (i.e., no relationship was found, $R^{2}=0.05$;
Table 3). Although most of the correlations at species level were significant, they only explain 2 to $39 \%$ of the variance in trends described, except for Halophila ovalis (91\%; Table 3). In particular, Posidonia meadows ( $P$. australis, $P$. sinuosa and $P$. oceanica) had the lower correlation values $\left(R^{2}\right.$ ranged from 0.02 to 0.15 ). When combining mud and $\mathrm{C}_{\text {org }}$ contents in seagrass meadows of the colonizing and opportunistic genera Halophila, Halodule and Zostera (Kilminster et al., 2015), a relatively high correlation was found ( $R^{2}=0.56$; Fig. 1 ), while soil $\mathrm{C}_{\text {org }}$ and mud contents in persistent genera were only slightly positively correlated in combined Amphibolis spp. and not correlated in Posidonia spp. meadows (Fig. 1).

The relationships between soil $\mathrm{C}_{\text {org }}$ and mud contents within different core depths (from 1 to $10 \mathrm{~cm}$ thick deposits, and from 11 to up to $110 \mathrm{~cm}$ thick deposits) for bare sediments and each group of seagrass species were explored in Fig. 2. The $\mathrm{C}_{\text {org }}$ content increased with increasing mud content in bare sediments for both 1 to $10 \mathrm{~cm}$ thick $\left(R^{2}=0.74\right)$ and 11 to $110 \mathrm{~cm}$ thick $\left(R^{2}=0.81\right)$ soils. When combining mud and $\mathrm{C}_{\text {org }}$ contents in seagrass meadows of the genera Halophila, Halodule and Zostera, a higher correlation was found for deeper core sections $(11$ to $110 \mathrm{~cm}$ thick; $R^{2}=0.74$ ) compared to top core sections ( 1 to $10 \mathrm{~cm}$ thick; $R^{2}=0.17$ ). For combined Amphibolis and Posidonia species, soil $\mathrm{C}_{\text {org }}$ and mud contents were only slightly pos- 

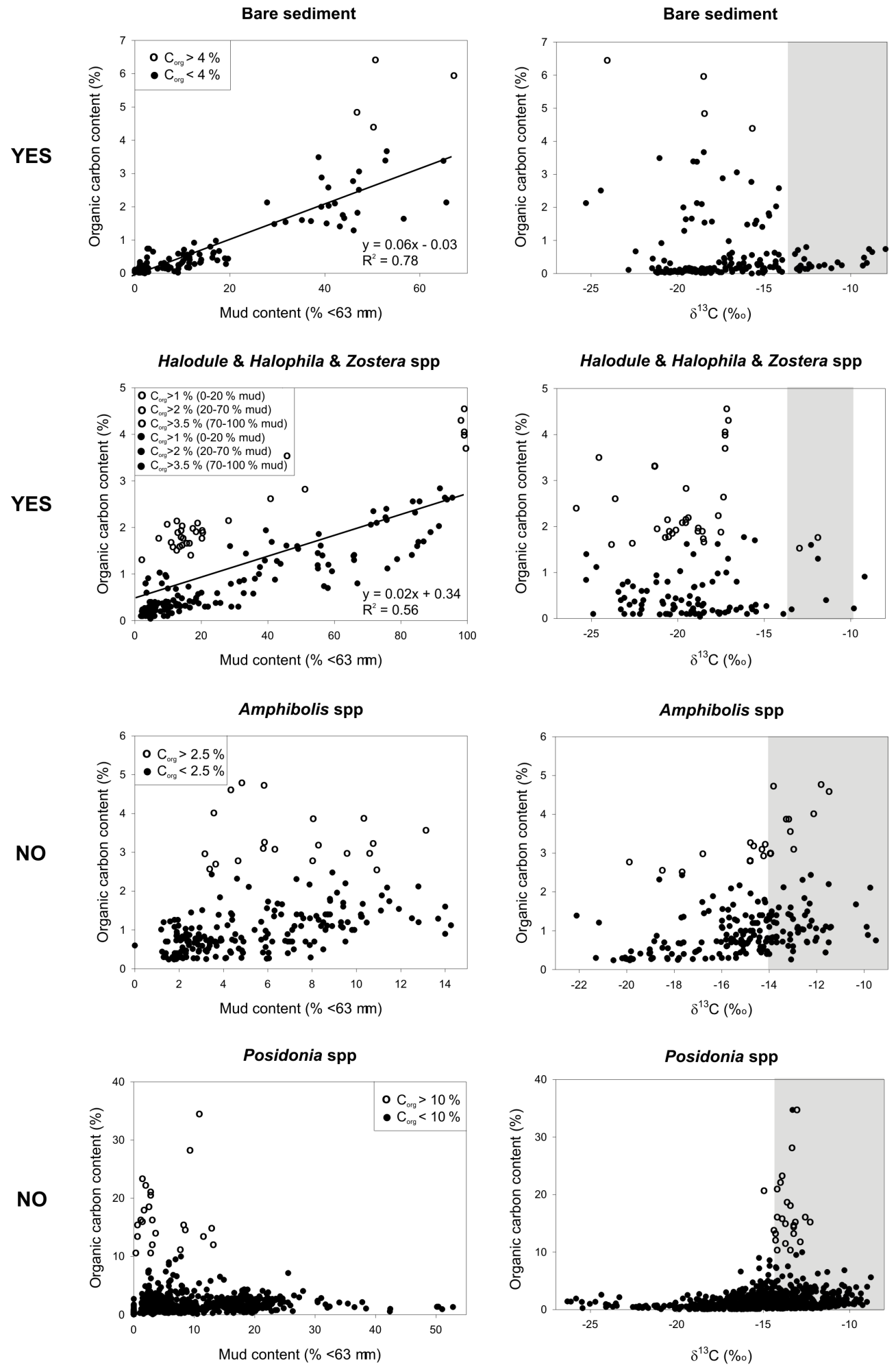

Figure 1. Relationships among soil $\mathrm{C}_{\mathrm{org}}$ and mud contents, and soil $\mathrm{C}_{\mathrm{org}}$ and $\delta^{13} \mathrm{C}$ signatures in all habitats and all soil depths studied: bare sediments, combined Halodule, Halophila and Zostera species, and combined Amphibolis and Posidonia species. Only correlations with $R^{2}>0.5$ are shown. The grey shaded areas showed the range of $\delta^{13} \mathrm{C}$ signatures of plant detritus (based on literature values; see main text). The white circles indicate the samples obviating the expected correlation between soil $\mathrm{C}_{\text {org }}$ and mud contents. 
Table 3. Pearson correlation analyses to test for significant relationships among soil $\mathrm{C}_{\text {org }}$ and mud contents, and soil $\mathrm{C}_{\text {org }}$ and $\delta^{13} \mathrm{C}$ signatures in up to $475 \mathrm{~cm}$ long cores; based on (a) species identity and (b) habitat geomorphology. ns, non significant correlation.

(a)

\begin{tabular}{|c|c|c|c|c|c|c|}
\hline \multirow{2}{*}{$\begin{array}{l}\text { Habitat } \\
\text { (species) }\end{array}$} & \multicolumn{3}{|c|}{ Organic carbon (\%) vs. mud (\%) } & \multicolumn{3}{|c|}{ Organic carbon $(\%)$ vs. $\delta^{13} \mathrm{C}(\% \circ)$} \\
\hline & Formula & $R^{2}$ & $P$ value & Formula & $R^{2}$ & $P$ value \\
\hline Posidonia oceanica & $\mathrm{C}_{\text {org }}=-0.26 \times \mathrm{mud}+6.95$ & 0.15 & $* * *$ & $\mathrm{C}_{\text {org }}=1.59 \times \delta^{13} \mathrm{C}+27.61$ & 0.13 & $* * *$ \\
\hline Posidonia australis & $\mathrm{C}_{\mathrm{org}}=0.02 \times \mathrm{mud}+1.69$ & 0.02 & $*$ & $\mathrm{C}_{\text {org }}=0.18 \times \delta^{13} \mathrm{C}+4.73$ & 0.30 & *** \\
\hline Posidonia sinuosa & $\mathrm{C}_{\text {org }}=0.07 \times \mathrm{mud}+0.61$ & 0.09 & $* * *$ & $\mathrm{C}_{\text {org }}=0.12 \times \delta^{13} \mathrm{C}+2.44$ & 0.23 & $* * *$ \\
\hline Amphibolis (mixed spp.) & $\mathrm{C}_{\text {org }}=0.17 \times \mathrm{mud}+0.61$ & 0.26 & $* * *$ & $\mathrm{C}_{\text {org }}=0.14 \times \delta^{13} \mathrm{C}+3.53$ & 0.09 & ** \\
\hline Amphibolis antarctica & $\mathrm{C}_{\text {org }}=0.08 \times \mathrm{mud}+0.47$ & 0.32 & $* * *$ & $\mathrm{C}_{\mathrm{org}}=0.14 \times \delta^{13} \mathrm{C}+3.10$ & 0.29 & $* * *$ \\
\hline Amphibolis griffithii & ns & 0.05 & 0.18 & $\mathrm{C}_{\text {org }}=0.06 \times \delta^{13} \mathrm{C}+1.79$ & 0.21 & ** \\
\hline Halodule uninervis & $\mathrm{C}_{\text {org }}=0.02 \times \mathrm{mud}+0.37$ & 0.34 & $* * *$ & ns & 0.00 & 0.89 \\
\hline Zostera muelleri & $\mathrm{C}_{\text {org }}=0.02 \times \operatorname{mud}+0.54$ & 0.39 & $* * *$ & ns & 0.08 & 0.07 \\
\hline Halophila ovalis & $\mathrm{C}_{\text {org }}=0.04 \times \mathrm{mud}+0.12$ & 0.91 & $* * *$ & ns & 0.00 & 0.89 \\
\hline Bare & $\mathrm{C}_{\text {org }}=0.06 \times \operatorname{mud}-0.03$ & 0.78 & $* * *$ & ns & 0.01 & 0.24 \\
\hline
\end{tabular}

(b)

\begin{tabular}{llrrrrr}
\hline \multirow{2}{*}{$\begin{array}{l}\text { Habitat } \\
\text { (geomorphology) }\end{array}$} & \multicolumn{2}{c}{ Organic carbon $(\%)$ vs. mud $(\%)$} & \multicolumn{2}{c}{ Organic carbon $(\%)$ vs. $\delta^{13} \mathrm{C}(\% \circ)$} \\
\cline { 2 - 7 } & Formula & $R^{2}$ & $P$ value & Formula & $R^{2}$ & $P$ value \\
\hline Coastal & $\mathrm{ns}$ & 0.01 & 0.85 & $\mathrm{C}_{\text {org }}=0.17 \times \delta^{13} \mathrm{C}+4.14$ & 0.03 & $* * *$ \\
Estuarine & $\mathrm{C}_{\text {org }}=0.02 \times$ mud +1.01 & 0.14 & $*$ & $\mathrm{C}_{\text {org }}=0.17 \times \delta^{13} \mathrm{C}+4.52$ & 0.22 & $* *$ \\
\hline
\end{tabular}

itively correlated in deeper Amphibolis spp. sections (11 to $110 \mathrm{~cm}$-thick; $R^{2}=0.23$ ) and not correlated in Posidonia spp. meadows (Fig. 2). The classification of habitats based on geomorphology (i.e., coastal and estuarine) showed a lack of correlation between soil $\mathrm{C}_{\text {org }}$ and mud contents in coastal ecosystems, and a poor correlation in estuarine ecosystems $\left(R^{2}=0.14\right.$; Fig. 3 and Table 3$)$.

The relationships between soil $\% \mathrm{C}_{\text {org }}$ and $\delta^{13} \mathrm{C}$ signatures were poor for all individual Amphibolis and Posidonia species studied ( $R^{2}$ ranging from 0.09 to 0.3 ; Table 3 ), and for combined Amphibolis spp. (Fig. 1), with a tendency of $\mathrm{C}_{\text {org }}$-rich soils being enriched in ${ }^{13} \mathrm{C}$ (Fig. 1). In contrast, $\% \mathrm{C}_{\mathrm{org}}$ and $\delta^{13} \mathrm{C}$ signatures were not correlated in any of the small and fast-growing Halodule, Zostera, Halophila meadows studied (Table 3), neither individually nor when combined (Fig. 1 and Table 3). A lack of correlation between soil $\% \mathrm{C}_{\mathrm{org}}$ and $\delta^{13} \mathrm{C}$ signatures was also found in bare sediments adjacent to seagrass meadows (Fig. 3 and Table 3 ).

\section{Discussion}

Overall mud content is a poor predictor of soil $\mathrm{C}_{\text {org }}$ in seagrass meadows and care should be taken in its use as a costeffective proxy or indicator of $\mathrm{C}_{\text {org }}$ for scaling-up purposes in the emerging field of blue carbon science. Although we describe some promise for opportunistic and early colonizing Halophila, Halodule and Zostera meadows (i.e., mud content explained 34 to $91 \%$ of variability in $\mathrm{C}_{\text {org }}$ content) and in bare sediments adjacent to seagrass meadows (explaining $78 \%$ of the variability), mud is not a universal proxy for blue carbon content and therefore should not be applied generally across all seagrass habitats. In particular, mud content only explained 5 to $32 \%$ of soil $\mathrm{C}_{\text {org }}$ content in Amphibolis spp. meadows and 2 to $15 \%$ of soil $\mathrm{C}_{\text {org }}$ content in Posidonia spp. meadows, and therefore, mud content is not a good proxy for blue carbon content in these meadows.

A tenet of carbon cycling within the coastal ocean is that fine-grained sediments (i.e., mud) have higher $\mathrm{C}_{\text {org }}$ contents. The positive relationship found between mud and $\mathrm{C}_{\text {org }}$ contents in coastal bare sediments (explaining $78 \%$ of the variability) is in agreement with previous studies (e.g., Bergamaschi et al., 1997; De Falco et al., 2004), and is related to their larger surface areas compared to coarse-grained sediments, providing more binding sites for $\mathrm{C}_{\text {org }}$ on the surface of minerals (Keil and Hedges, 1993; Mayer, 1994a, b; Galy et al., 2007; Burdige, 2007). In addition, the predominance of fine sediments reduces oxygen exchange and results in low sediment redox potentials and remineralization rates, contributing to the preservation of sedimentary $\mathrm{C}_{\text {org }}$ after burial (Hedges and Keil, 1995; Bergamaschi et al., 1997; Dauwe et al., 2001; Burdige 2007; Pedersen et al., 2011). However, the maximum capacity of a given soil to preserve $\mathrm{C}_{\text {org }}$ by their association with clay and silt particles is limited (i.e., mud$\mathrm{C}_{\text {org }}$ saturation; Hassink, 1997). The results obtained showed that bare sediment samples with relatively high $\mathrm{C}_{\text {org }}$ contents (i.e., $>4 \% \mathrm{C}_{\text {org }}$ ) and relatively low mud contents were also 

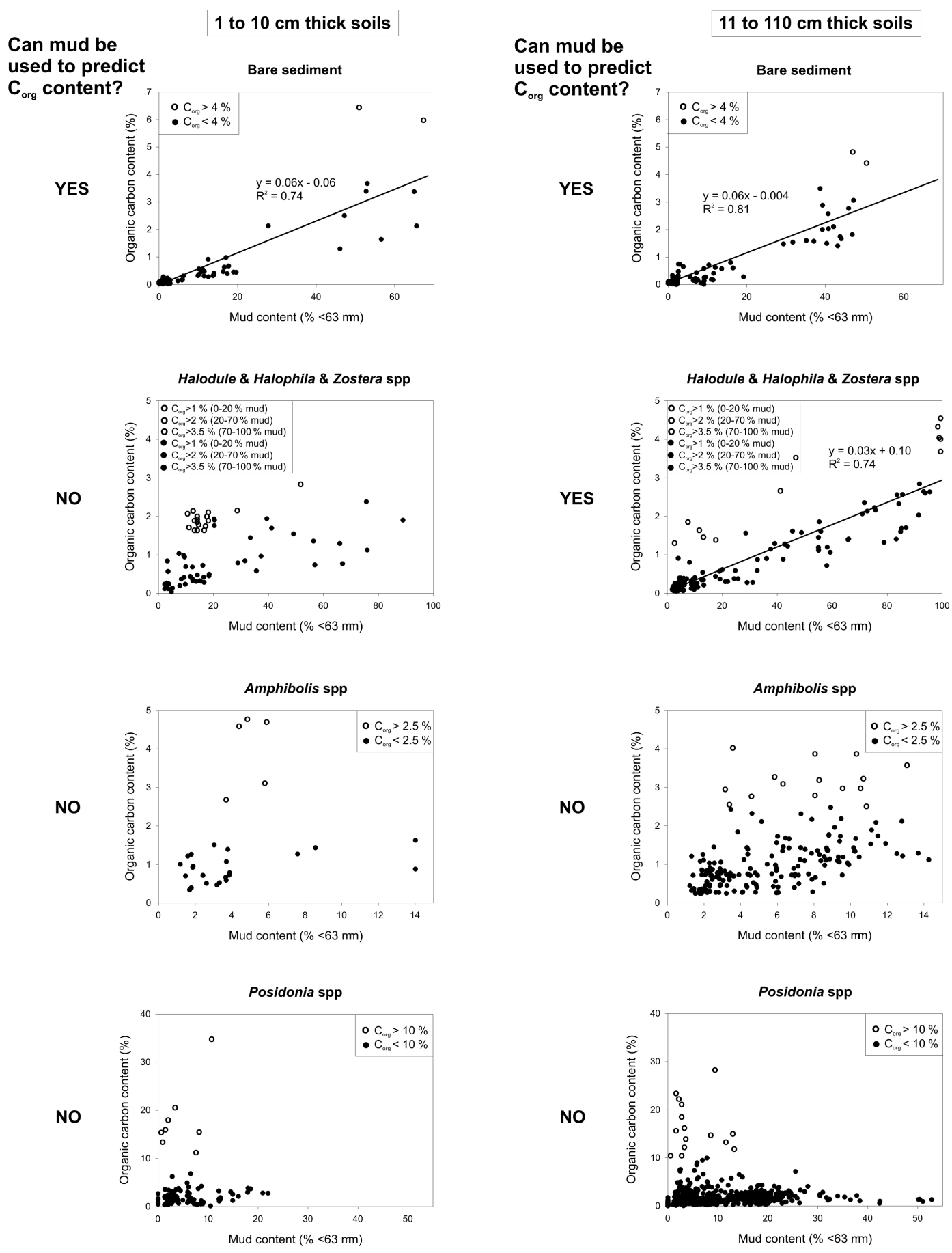

Figure 2. Relationships among soil $\mathrm{C}_{\text {org }}$ and mud contents in 1 to $10 \mathrm{~cm}$ and 11 to $110 \mathrm{~cm}$ thick soils: bare sediments, combined Halodule, Halophila and Zostera species, and combined Amphibolis and Posidonia species. Only correlations with $R^{2}>0.5$ are shown. The white circles indicate the samples obviating the expected correlation between soil $\mathrm{C}_{\text {org }}$ and mud contents.

${ }^{13} \mathrm{C}$-depleted (Fig. 1), suggesting significant contributions of soil $\mathrm{C}_{\text {org }}$ from allochthonous sources (e.g., terrestrial and sestonic; Kennedy et al., 2010). This could have disrupted the correlation found between soil $\mathrm{C}_{\text {org }}$ and mud contents in the bare sediments studied.
Mud is not a universal proxy for soil $\mathrm{C}_{\text {org }}$ content in seagrass meadows, which could be mainly explained by additional inputs of seagrass-derived $\mathrm{C}_{\text {org }}$ and/or allochthonous $\mathrm{C}_{\text {org }}$ to the sedimentary $\mathrm{C}_{\text {org }}$ pool, obviating the linear relationship between mud and $\mathrm{C}_{\text {org }}$ contents found in the absence 

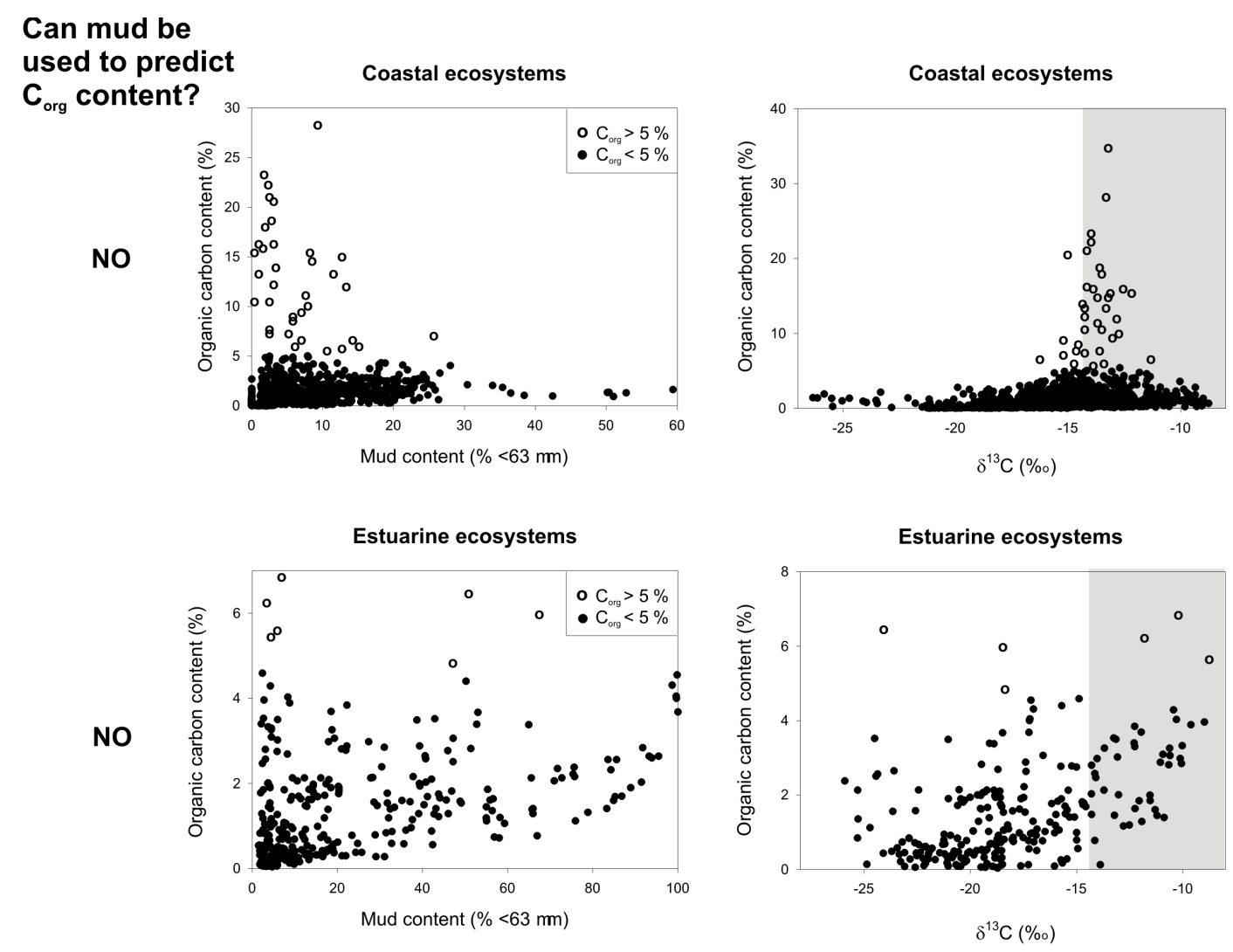

Figure 3. Relationships among soil $\mathrm{C}_{\text {org }}$ and mud contents, and soil $\mathrm{C}_{\text {org }}$ and $\delta^{13} \mathrm{C}$ signatures in the coastal and estuarine habitats studied. The grey shaded areas showed the range of $\delta^{13} \mathrm{C}$ signatures of plant detritus (based on literature values; see main text). The white circles indicate the samples obviating the expected correlation between soil $\mathrm{C}_{\text {org }}$ and mud contents.

of vegetation. The $\delta^{13} \mathrm{C}$ values indicated that both seagrass$\mathrm{C}_{\mathrm{org}}$ and non-seagrass-derived $\mathrm{C}_{\mathrm{org}}$ (i.e., epiphytes, algae, seston or terrestrial matter) were buried in the soils of all studied meadows, but are consistent with a model of increasing capture of seagrass-derived $\mathrm{C}_{\text {org }}$ at meadows formed by persistent, high-biomass seagrasses (i.e., genera Posidonia and Amphibolis) relative to opportunistic, low-biomass seagrasses (i.e., genera Halophila, Halodule and Zostera).

On one hand, the soil $\delta^{13} \mathrm{C}$ signatures measured in these long-living and large seagrass meadows (averaging $-15 \pm 0.2 \%$ in both cases) were closer to the $\delta^{13} \mathrm{C}$ signatures of Posidonia and Amphibolis tissues (ranging from -8 to $-14 \%$; Hyndes and Lavery, 2005; Hindell et al., 2004; Cardona et al., 2007; Fourqurean et al., 2007; Collier et al., 2008; Kennedy et al., 2010; Hanson et al., 2010; Serrano et al., 2016) than to $\delta^{13} \mathrm{C}$ values of algae or terrestrial organic matter (ranging from -18 to $-32 \%$; e.g., Smit et al., 2006; Cardona et al., 2007; Kennedy et al., 2010; Hanson et al., 2010; Deudero et al., 2011). The poor relationship between mud and soil $\mathrm{C}_{\text {org }}$ contents in Amphibolis soils could be explained by samples with relatively high $\mathrm{C}_{\text {org }}$ contents (i.e., $>2.5 \% \mathrm{C}_{\text {org }}$ ) and relatively low mud contents, as a result of both the contribution of seagrass-derived $\mathrm{C}_{\text {org }}$ (i.e.,
${ }^{13} \mathrm{C}$-enriched) and $\mathrm{C}_{\text {org }}$ from allochthonous sources (i.e., ${ }^{13} \mathrm{C}$-depleted; Fig. 1). In Posidonia soils, the poor relationship between mud and soil $\mathrm{C}_{\text {org }}$ contents could be explained by samples with relatively high $\mathrm{C}_{\text {org }}$ contents (i.e., $>10 \%$ $\mathrm{C}_{\text {org }}$ ) and relatively low mud contents, as a result of the contribution of seagrass-derived $\mathrm{C}_{\text {org }}$ (i.e., ${ }^{13} \mathrm{C}$-enriched; Fig. 1). The contribution of seagrass-derived $\mathrm{C}_{\text {org }}$ (i.e., root, rhizome and sheath detritus) in Posidonia soils play a much larger role than the accumulation of fine, organic-rich allochthonous particles.

On the other hand, the soil $\delta^{13} \mathrm{C}$ signatures measured in Halodule, Halophila and Zostera meadows (averaging $-21 \pm 0.4 \%$ ) were more similar to $\delta^{13} \mathrm{C}$ values of algae or terrestrial organic matter than to $\delta^{13} \mathrm{C}$ values of their seagrass tissues (ranging from -10 and $-14 \%$; e.g., Hemminga and Mateo, 1996; Kennedy et al., 2010; Hanson et al., 2010). The positive relationship between mud and soil $\mathrm{C}_{\text {org }}$ contents in Halodule, Halophila and Zostera soils could be explained by their relatively high mud content and ${ }^{13} \mathrm{C}$-depleted $\mathrm{C}_{\text {org }}$, indicating that allochthonous $\mathrm{C}_{\text {org }}$ inputs and mud content play a major role in soil $\mathrm{C}_{\text {org }}$ accumulation in these opportunistic and early-colonizing seagrasses. However, the relatively high $\mathrm{C}_{\text {org }}$ contents found with relatively low mud 
contents (i.e., mud- $\mathrm{C}_{\text {org }}$ saturation) disrupted the correlation found between soil $\mathrm{C}_{\text {org }}$ and mud contents in these meadows $\left(\mathrm{C}_{\text {org }}>1 \%\right.$ in samples with $0-20 \%$ mud; $\mathrm{C}_{\text {org }}>2 \%$ in samples with $20-70 \%$ mud and $\mathrm{C}_{\text {org }}>3.5$ in samples with 70-100\% mud; Fig. 1).

The results obtained showed a tendency for high-biomass and persistent meadows (i.e., Posidonia and Amphibolis) to accumulate higher $\mathrm{C}_{\text {org }}$ stores and seagrass-derived $\mathrm{C}_{\text {org }}$ compared to ephemeral and low-biomass meadows (i.e., Halophila, Halodule and Zostera), suggesting that factors (biotic and abiotic) affecting the production, form and preservation of $\mathrm{C}_{\text {org }}$ within habitats exert a significant influence on soil $\mathrm{C}_{\text {org }}$ content (Lavery et al., 2013; Serrano et al., 2014, 2016). The above- and below-ground biomass in meadows of the genus Posidonia (averaging 535 and $910 \mathrm{~g} \mathrm{DW} \mathrm{m}^{-2}$, respectively) is up to 2-fold higher than in Amphibolis meadows (averaging 641 and $457 \mathrm{~g} \mathrm{DW} \mathrm{m}^{-2}$, respectively) and 4 to 18-fold higher than in small and opportunistic seagrasses of the genera Halophila, Halodule and Zostera (125 and $49 \mathrm{~g} \mathrm{DW} \mathrm{m}^{-2}$, on average; respectively; Duarte and Chiscano, 1999; Paling and McComb, 2000). Indeed, larger seagrasses tend to have larger and more persistent rhizomes, constituted by more refractory forms of $\mathrm{C}_{\text {org }}$, more prone to be preserved in soils than simpler, more labile forms of $\mathrm{C}_{\text {org }}$ such as seston and algal detritus which are more suitable to experience remineralization during early diagenesis (Henrichs, 1992; Burdige, 2007). In addition, the larger size of detritus within Amphibolis and Posidonia meadows compared to Halophila, Halodule and Zostera meadows could also contribute to the larger accumulation of $\mathrm{C}_{\text {org }}$ in the former, since decay rates of seagrass detritus increase with decreasing particle size due to larger surfaces available for microbial attack (Harrison, 1989). Differences in above- and below-ground biomass and recalcitrance between Posidonia and Amphibolis spp. could explain the larger contribution of seagrass-derived $\mathrm{C}_{\mathrm{org}}$ (i.e., ${ }^{13} \mathrm{C}$-enriched) in the former, thereby obviating the linear relationship between mud and $\mathrm{C}_{\text {org }}$ contents (Fig. 1).

The soil $\mathrm{C}_{\text {org }}$ content tends to decrease with soil depth and ageing in seagrass ecosystems (e.g., Serrano et al., 2012), thereby the persistence of discrete organic detritus within upper soil horizons could lead to organic matter concentrations above those levels explained by the association with clay and silt particles, as previously demonstrated for terrestrial soils (Mayer and Xing, 2001; Gami et al., 2009). The organic matter preserved in most marine sediments is intimately associated with mineral surfaces (i.e., selective preservation by sorption of organic matter into minerals; Keil et al., 1994) and therefore the correlation between soil $\mathrm{C}_{\text {org }}$ and mud contents in seagrass meadows could vary as a function of soil depth and ageing. The results obtained show that soil depth is not an important factor when attempting to predict soil $\mathrm{C}_{\text {org }}$ content based on mud content in bare sediments (i.e., $R^{2}>0.74$ for all core depths explored; 1 to 110,1 to 10 , and 11 to $110 \mathrm{~cm}$ thick; Fig. 2). However, a clearer pattern appeared when exploring the correlation between soil $\mathrm{C}_{\mathrm{org}}$ and mud contents in top $10 \mathrm{~cm}$ and within $11-110 \mathrm{~cm}$ soil depths of combined Halodule, Halophila and Zostera species ( $R^{2}=0.17$ and $R^{2}=0.74$, respectively). These results suggest that the relatively small below-ground biomass of these species (i.e., organic detritus) only has an impact on the expected positive correlation between soil $\mathrm{C}_{\text {org }}$ and mud content within the top $10 \mathrm{~cm}$, while the correlation for deeper soil depths $(11-110 \mathrm{~cm})$ improved $\left(R^{2}=0.74\right)$ compared to the whole data set ( 1 to $110 \mathrm{~cm}$ thick; $R^{2}=0.56$ ). For combined Amphibolis and Posidonia species, the results obtained show that soil depth is not an important factor when attempting to predict soil $\mathrm{C}_{\text {org }}$ content based on mud content (i.e., $R^{2}<0.2$ in all cases; 1 to 110,1 to 10 , and 11 to $110 \mathrm{~cm}$ thick; Fig. 2). These results suggest that the relatively large belowground biomass of these species (i.e., organic detritus) has an impact on the expected positive correlation between soil $\mathrm{C}_{\text {org }}$ and mud content within all depths studied.

Habitat conditions in seagrass meadows not only influence the amount of $\mathrm{C}_{\text {org }}$ accumulation through detrital plant inputs, but the capacity of the plant canopies to retain particles (Gacia et al., 1999). The amount of fine suspended particles available for burial varies among sites, driven by geomorphological features (e.g., run-off, hydrodynamic energy and water depth), while meadow structure (i.e., density, cover and morphology of the canopy) constrains their capacity to accumulate sediment particles (Hendriks et al., 2010; Peralta et al., 2008). Although the number of cores and species studied in coastal and estuarine ecosystems was unbalanced (i.e., Amphibolis and Posidonia dominate in coastal habitats and Halophila, Halodule, Zostera dominate in estuarine habitats), the lack of, or poor correlations found within estuarine and coastal ecosystems, precludes the general use of mud as a predictor of blue carbon content based on habitat geomorphology (Fig. 3). Seagrass meadows and bare sediments in environments conducive for depositional processes (i.e., estuaries) accumulated up to 4-fold higher amounts of mud compared to other coastal ecosystems, but the saturation of mud with $\mathrm{C}_{\text {org }}$ and the large contribution of seagrass detritus into the sedimentary $\mathrm{C}_{\text {org }}$ pool $\left({ }^{13} \mathrm{C}\right.$-enriched soils $)$ in some study sites disrupted the positive relationship expected between mud and soil- $\mathrm{C}_{\text {org }}$ contents. In estuarine ecosystems, soil $\mathrm{C}_{\text {org }}$ originated from both mud inputs linked to allochthonous- $\mathrm{C}_{\text {org }}$ via deposition from upstream transport (e.g., Aller, 1998) and seagrass inputs (i.e., in samples with $\mathrm{C}_{\mathrm{org}}>5 \%$; Fig. 3). The insignificant relationship between mud and soil $\mathrm{C}_{\text {org }}$ contents in coastal habitats could be explained by their relatively low mud content and the accumulation of seagrass-derived $\mathrm{C}_{\mathrm{org}}$, in particular in samples with $\mathrm{C}_{\text {org }}>5 \%$ (Fig. 3).

In sum, mud is not a universal proxy for blue carbon content in seagrass ecosystems and should not be applied generally across all habitat and vegetation types. Overall, the positive relationship between mud and $\mathrm{C}_{\text {org }}$ contents found in bare sediments and in opportunistic and/or low 
biomass seagrass meadows (i.e., genera Zostera, Halodule and Halophila) allow mud to be used as a proxy for $\mathrm{C}_{\text {org }}$ content in these ecosystems, thereby enabling robust scaling up exercises (i.e., benefiting from existing geological surveys and models) at low cost as part of blue carbon stock assessment programs. However, mud content is not a good predictor of $\mathrm{C}_{\text {org }}$ content in highly productive meadows such as those constituted by $P$. oceanica in the Mediterranean Sea and P. australis, P. sinuosa and Amphibolis spp. in Australia. Analyses of soil grain size (i.e., \%mud) could constitute a relatively cheap method to estimate soil organic carbon content in seagrass ecosystems, particularly dry and wet sieving using standard geological sieves (Erftemeijer and Koch, 2001). These could be used to cheaply quantify mud content as a proxy for carbon, particularly in student projects, citizen science and in countries where funding for science is limited and they do not have access to higher technology methods or cannot afford to pay for analysis. In addition, since most countries have conducted geological surveys within the coastal zone to determine sediment grain size (e.g., Passlow et al., 2005), a strong, positive relationship between mud and $\mathrm{C}_{\text {org }}$ contents could allow the development of geomorphology models to predict blue carbon content within seagrass meadows, dramatically improving global estimates of blue carbon storage. Indeed, maps of soil grain-size could be obtained using remote sensing (Rainey et al., 2003; De Falco et al., 2010), opening new opportunities for scaling exercises.

Previous studies suggested that the relationship between organic matter and the sediment matrix is best seen with claysized fractions $(<0.004 \mathrm{~mm}$; Bergamaschi et al., 1997; De Falco et al., 2004). However, the grain size cut-off selected in this study (mud, $<0.063 \mathrm{~mm}$ ) is more representative of the bulk soil and their $\mathrm{C}_{\text {org }}$ content (Pedrosa-Pàmies et al., 2013) and therefore a higher correlation is expected when comparing bulk soil $\mathrm{C}_{\text {org }}$ with a larger and more representative fraction of the sediment (i.e., including the silt fraction, $0.004-0.063 \mathrm{~mm}$, also provides binding sites for $\mathrm{C}_{\text {org }}$; Burdige, 2007). Other biological, chemical and geological factors not explored in detail in this study may also play a key role in $\mathrm{C}_{\text {org }}$ storage, and ultimately in the relationship between soil $\mathrm{C}_{\text {org }}$ and mud contents. For example, the effects of habitat geomorphology (e.g., hydrodynamic energy, terrestrial mud and $\mathrm{C}_{\text {org }}$ inputs, export of seagrass biomass) and species identity (e.g., variation in terms of productivity, oxygen exposure and recalcitrance of $\mathrm{C}_{\text {org }}$ stores, and plant influence on sediment retention) within both coastal and estuarine environments, are among the factors identified in this study which might explain significant variation in the $\mathrm{C}_{\text {org }}$ stores of meadows in relatively similar exposure conditions (Serrano et al., 2016). Other factors found to play a key role in controlling soil $\mathrm{C}_{\text {org }}$ accumulation in terrestrial ecosystems, such as chemical stabilization of organic matter (Percival et al., 1999; Galy et al., 2008) and microbial biomass carbon (Danovaro et al., 1994), could also influence $C_{\text {org }}$ storage in seagrass ecosystems. Further studies are needed to identify the influences of these other factors on $\mathrm{C}_{\text {org }}$ storage in seagrass meadows, and in addition to the mud content, other characteristics should be taken into account when attempting to obtain robust estimates of $\mathrm{C}_{\text {org }}$ stores within coastal areas.

\section{Data availability}

The raw data compiled for this study was published in ECU Research Online Portal (doi:10.4225/75/56c55ab91d417).

Acknowledgements. This work was supported by the ECU Faculty Research Grant Scheme, the ECU Early Career Research Grant Scheme, and the CSIRO Flagship Marine \& Coastal Carbon Biogeochemical Cluster (Coastal Carbon Cluster) with funding from the CSIRO Flagship Collaboration Fund. Peter Macreadie was supported by an ARC DECRA DE130101084. The authors are grateful to M. Rozaimi, A. Gera, P. Bouvais, A. Ricart, C. Bryant, G. Skilbeck, M. Rozaimi, A. Esteban, M. A. Mateo, P. Donaldson, C. Sharples and R. Mount for their help in field and/or laboratory tasks.

Edited by: G. Abril

Reviewed by: M. Plus and two anonymous referees

\section{References}

Adame, M. F., Kauffman, J. B., Medina, I., Gamboa, J. N., Torres, O., Caamal J. P., Reza, M., and Herrera-Silveira, J.: Carbon stocks of tropical coastal wetlands within the karstic landscape of the Mexican Caribbean, PLoS ONE, 8, e56569, doi:10.1371/journal.pone.0056569, 2013.

Aller, R. C.: Mobile deltaic and continental shelf muds as suboxic, fluidized bed reactors, Mar. Chem., 61, 143-155, 1998.

Amundson, R.: The carbon budget in soils, Annu. Rev. Earth Pl. Sc., 29, 535-562, 2001.

Bergamaschi, B. A., Tsamakis, E., Keil, R. G., and Eglinton, T. I.: The effect of grain size and surface area on organic matter, lignin and carbohydrate concentration, and molecular compositions in Peru Margin sediments, Geochem. Cosmochim. Ac., 61, 12471260, 1997.

Burdige, D. J.: Preservation of Organic Matter in Marine Sediments: Controls, Mechanisms, and an Imbalance in Sediment Organic Carbon Budgets?, Chem. Rev., 107, 467-485, doi:10.1021/cr050347q, 2007.

Cardona, L., Revelles, M., Sales, M., Aguilar, A., and Borrell, A.: Meadows of the seagrass Posidonia oceanica are a significant source of organic matter for adjoining ecosystems, Mar. Ecol.Prog. Ser., 335, 123-131, 2007.

Carruthers, T. J. B., Dennison, W. C., Kendrick, G. A., Waycott, M., Walker, D. I., and Cambridge, M. L.: Seagrasses of south-west Australia: A conceptual synthesis of the world's most diverse and extensive seagrass meadows, J. Exp. Mar. Biol. Ecol., 350, 2145, doi:10.1016/j.jembe.2007.05.036, 2007.

Collier, C. J., Lavery, P. S., Masini, R. J., and Ralph, P.: Physiological characteristics of the seagrass Posidonia sinuosa along a 
depth-related gradient of light availability, Mar. Ecol.-Prog. Ser., 353, 65-79, 2008.

Danovaro, R., Fabiano, M., and Boyer, M.: Seasonal changes of benthic bacteria in a seagrass bed (Posidonia oceanica) of the Ligurian Sea in relation to origin, composition and fate of the sediment organic matter, Mar. Biol., 119, 489-500, 1994.

Danovaro, R., Della Croce, N., Eleftheriou, A., Fabiano, M., Papadopoulou, N., Smith, C., and Tselepides, A.: Meiofauna of the deep Eastern Mediterranean Sea: distribution and abundance in relation to bacterial biomass, organic matter composition and other environmental factors, Prog. Oceanogr., 36, 329-341, 1995.

Dauwe, B., Middelburg, J. J., and Herman, P. M. J.: Effect of oxygen on the degradability of organic matter in subtidal and intertidal sediments of the North Sea area, Mar. Ecol.-Prog. Ser., 215, 1322, 2001.

De Deyn, G. B., Cornelissen, J. H., and Bardgett, R. D.: Plant functional traits and soil carbon sequestration in contrasting biomes, Ecol. Lett., 11, 516-531, doi:10.1111/j.14610248.2008.01164.x, 2008.

De Falco, G., Magni, P., Teräsvuori, L. M. H., and Matteucci, G.: Sediment grain size and organic carbon distribution in the Cabras lagoon (Sardinia, Western Mediterranean), Chem. Ecol., 20, 367-377, doi:10.1080/02757540310001629189, 2004.

De Falco, G., Tonielli, R., Di Martino, G., Innangi, S., Simeone, S., and Parnum, I.M.: Relationships between multibeam backscatter, sediment grain size and Posidonia oceanica seagrass distribution, Cont. Shelf Res., 30, 1941-1950, 2010.

Deudero, S., Box, A., Alós, J., Arroyo, N. L., and Marbà, N.: Functional changes due to invasive species: Food web shifts at shallow Posidonia oceanica seagrass beds colonized by the alien macroalga Caulerpa racemosa, Estuar. Coast. Shelf S., 93, 106116, 2011.

Donato, D. C., Kauffman, J. B., Murdiyarso, D., Kurnianto, S., Stidham, M., and Kanninen, M.: Mangroves among the most carbon-rich forests in the tropics, Nat. Geosci., 4, 293-297, doi:10.1038/ngeo1123, 2011.

Duarte, C. and Chiscano, C. L.: Seagrass biomass and production: a reassessment, Aquat. Bot., 65, 159-174, 1999.

Duarte, C. M., Marbà, N., Gacia, E., Fourqurean, J. W., Beggins, J., Barrón, C., and Apostolaki, E. T.: Seagrass community metabolism: Assessing the carbon sink capacity of seagrass meadows, Global Biogeochem. Cy., 24, GB4032, doi:10.1029/2010GB003793, 2010.

Erftemeijer, P. L. and Koch, E. W.: Sediment geology methods for seagrass habitat, in: Global seagrass research methods, edited by: Short, F. T. and Coles, R. G., 345-367, 2001.

Fourqurean, J. W., Marba, N., Duarte, C. M, Diaz-Almela, E., and Ruiz-Halpern, S.: Spatial and temporal variation in the elemental and stable isotopic content of the seagrass Posidonia oceanica and Cymodocea nodosa from the Illes Balears, Spain, Mar. Biol., 151, 219-232, 2007.

Gacia, E., Granata, T. C., and Duarte, C. M.: An approach to measurement of particle flux and sediment retention within seagrass (Posidonia oceanica) meadows, Aquat. Bot., 65, 255-268, 1999.

Galy, V., France-Lanord, C., Beyssac, O., Faure, P., Kudrass, H., and Palhol, F.: Efficient organic carbon burial in the Bengal fan sustained by the Himalayan erosional system, Nature, 450, 407410, 2007.
Galy, V., Beyssac, C., France-Lanord, C., and Eglinton, T.: Recycling of graphite during Himalayan erosion: a geological stabilization of carbon in the crust, Science, 322, 943-945, 2008.

Gami, S. K., Lauren, J. G., and Duxbury, J. M.: Influence of soil texture and cultivation on carbon and nitrogen levels in soils of the eastern Indo-Gangetic plains, Geoderma, 153, 304-311, 2009.

Hanson, C. E., Hyndes, G. A., and Fang Wang, S.: Differentiation of benthic marine primary produces using stable isotopes and fatty acids: implications to food web studies, Aquat. Bot., 93, 114$122,2010$.

Harrison, P. G.: Detrital processing in seagrass systems: A review of factors affecting decay rates, remineralization and detritivory, Aquat. Bot., 35, 263-288, 1989.

Hassink, J.: The capacity of soils to preserve organic $\mathrm{C}$ and $\mathrm{N}$ by their association with clay and silt particles, Plant Soil, 191, 7787, 1997.

Hedges, J. I. and Keil R. G.: Sedimentary organic matter preservation: An assessment and speculative synthesis, Mar. Chem., 49, 81-115, 1995.

Hemminga, M. A. and Mateo, M. A.: Stable carbon isotopes in seagrasses: Variability in ratios and use in ecological studies, Mar. Ecol.-Prog. Ser., 140, 285-298, 1996.

Hendriks, I. E., Bouma T. J., Morris E. P., and Duarte C. M.: Effects of seagrasses and algae of the Caulerpa family on hydrodynamics and particle-trapping rates, Mar. Biol., 157, 473-481, 2010.

Henrichs, S. M.: Early diagenesis of organic matter in marine sediments: progress and perplexity, Mar. Chem., 39, 119-149, 1992.

Hindell, J., Jenkins, G., Connolly, R., and Hyndes, G. A.: Assessment of the Importance of Different Near-shore Marine Habitats to Important Fishery Species in Victoria Using Standardised Survey Methods, and in Temperate and Sub-tropical Australian Using Stable Isotope Analysis, Fisheries Research and Development Corporation and Primary Industries Research Victoria, 2004.

Hyndes, G. A. and Lavery, P. S.: Does transported seagrass provide an important trophic link in unvegetated, nearshore areas?, Estuar. Coast. Shelf S., 63, 633-643, 2005.

Hyndes, G. A., Nagelkerken, I., McLeod, R. J., Connolly, R. M., Lavery, P. S., and Vanderklift, M. A.: Mechanisms and ecological role of carbon transfer within coastal seascapes, Biol. Rev. Camb. Philos., 89, 232-254, 2014.

Jonsson, M. and Wardle, D. A.: Structural equation modelling reveals plant-community drivers of carbon storage in boreal forest ecosystems, Biol. Lett., doi:10.1098/rsbl.2009.0613, 2009.

Keil, R. and Hedges, J.: Sorption of organic matter to mineral surfaces and the preservation of organic matter in coastal marine sediments, Chem. Geol., 107, 385-388, 1993.

Keil, R. G., Montluçon, D. B., Prahl, F. G., and Hedges, J. I.: Sorptive preservation of labile organic matter in marine sediments, Nature, 370, 549-552, 1994.

Kennedy, H., Beggins, J., Duarte, C. M., Fourqurean, J. W., Holmer, M., Marba, N., and Middelburg, J.: Seagrass sediments as a global carbon sink: Isotopic constraints, Global Biogeochem. Cy., 24, 1-9, 2010.

Kilminster, K., McMahon, K., Waycott, M., Kendrick, G. A., Scanes, P., McKenzie, L., O’Brien, K. R., Lyons, M., Ferguson, A., Maxwell, P., Glasby, T., and Udy, J.: Unravelling complexity in seagrass systems for management: Australia as a microcosm, Sci. Total Environ., 534, 97-109, 2015. 
Lavery, P. S., Mateo, M. A., Serrano, O., and Rozaimi, M.: Variability in the carbon storage of seagrass habitats and its implications for global estimates of blue carbon ecosystem service, PLoS One, 8, e73748, doi:10.1371/journal.pone.0073748, 2013.

Mateo, M. A., Romero, J., Pérez, M., Littler, M. M., and Littler, D. S.: Dynamics of Millenary Organic Deposits Resulting from the Growth of the Mediterranean Seagrass Posidonia oceanica, Estuar. Coast. Shelf S., 44, 103-110, 1997.

Mayer, L. M.: Surface area control of organic carbon accumulation in continental shelf sediments, Geochim. Cosmochim. Ac., 58, 1271-1284, 1994a.

Mayer, L. M.: Relationships between mineral surfaces and organic carbon concentrations in soils and sediments, Chem. Geol., 114, 347-363, 1994b.

Mayer, L. M. and Xing, B.: Organic matter-surface area relationships in acid soils, Soil Sci. Soc. Am. J., 65, 250-258, 2001.

McGrath, D. and Zhang, C.: Spatial distribution of soil organic carbon concentrations in grassland of Ireland, Appl. Geochem., 18, 1629-1639, 2003.

Nellemann, C., Corcoran, E., Duarte, C., Valdés, L., DeYoung, C., Fonseca, L., and Grimsditch, G. (Eds): Blue carbon. A rapid response assessment, United Nations Environ, Program, GRIDArendal, www.grida.no, last access: August 2015, 2009.

Nichols, J. D.: Relation of organic carbon to soil properties and climate in the Southern Great Plains, Soil Sci. Soc. Am. J., 48, 1382-1384, 1984.

Ouyang, X. and Lee, S. Y.: Updated estimates of carbon accumulation rates in coastal marsh sediments, Biogeosciences, 11, 50575071, doi:10.5194/bg-11-5057-2014, 2014.

Paling, E. I. and McComb, A. J.: Autumn biomass, below-ground productivity, rhizome growth at bed edge and nitrogen content in seagrasses from Western Australia, Aquat. Bot., 67, 207-219, 2000.

Passlow, V., Rogis, J., Hancock, A., Hemer, M., Glenn, K., and Habib, A.: Final Report, National Marine Sediments Database and Seafloor Characteristics Project, Geoscience Australia, Record 2005/08, 2005.

Pedersen, M. Ø., Serrano O., Mateo M. A., and Holmer M.: Decomposition of Posidonia oceanica matte in a climate change setting, Aquat. Microb. Ecol., 65, 169-182, 2011.

Pedrosa-Pàmies, R., Sanchez-Vidal, A., Calafat, A., Canals, M., and Durán, R.: Impact of storm-induced remobilization on grain size distribution and organic carbon content in sediments from the Blanes Canyon area, NW Mediterranean Sea, Prog. Oceanogr., $118,122-136,2013$.
Peralta, G., Van Duren, L. A., Morris, E. P., and Bouma, T. J.: Consequences of shoot density and stiffness for ecosystem engineering by benthic marcrophytes in flow dominated areas: a hydrodynamic flume study, Mar. Ecol.-Prog. Ser., 368, 103-115, 2008.

Percival, H. J., Parfitt, R. L., and Scott, N. A.: Factors controlling soil carbon levels in New Zealand grasslands is clay content important?, Soil Sci. Soc. Am. J., 64, 1623-1630, 1999.

Rainey, M. P., Tyler, A. N., Gilvear, D. J., Bryant, R. G., and McDonald, P.: Mapping intertidal estuarine sediment grain-size distributions through airbone remote sensing, Remote Sens. Environ., 86, 480-490, 2003.

Romero, J. and Pergent, G.: The detritic compartment in a Posidonia oceanica meadow litter features decomposition rates and mineral stocks, Mar. Ecol., 13, 69-83, 1992.

Rozaimi, M., Serrano, O., and Lavery, P. S.: Comparison of carbon stores by two morphologically different seagrasses, J. R. Soc. West. Aust., 96, 81-83, 2013.

Serrano, O., Mateo, M. A., Renom P., and Julià, R.: Characterization of soils beneath a Posidonia oceanica meadow, Geoderma, 185186, 26-36, 2012

Serrano, O., Lavery, P. S., Rozaimi, M., and Mateo, M. A.: Influence of water depth on the carbon sequestration capacity of seagrasses, Global Biogeochem. Cy., 301-314, doi:10.1002/2014GB004872, 2014.

Serrano, O., Ricart, A. M., Lavery, P. S., Mateo, M. A., Arias-Ortiz, A., Masque, P., Rozaimi, M., Steven, A., and Duarte, C. M.: Key biogeochemical factors affecting soil carbon storage in Posidonia meadows, Biogeosciences, 13, 4581-4594, doi:10.5194/bg-134581-2016, 2016.

Serrano, O., Lavery, P. S., Duarte, C. M., Kendrick, G. A., Calafat, A., York, P., Stevens, A., and Macreadie, P.: Can mud (silt and clay) concentration be used to predict soil organic carbon content within seagrass ecosystems? [dataset], Edith Cowan University, doi:10.4225/75/56c55ab91d417, 2015.

Smit, A. J., Brearley, A., Hyndes, G. A., Lavery, P. S., and Walker D. I.: $\delta^{13} \mathrm{C}$ and $\delta^{15} \mathrm{~N}$ analysis of a Posidonia sinuosa seagrass bed, Aquat. Bot., 84, 277-282, 2006.

Sparling, G. P.: Ratio of microbial biomass carbon to soil organic carbon as a sensitive indicator of changes in soil organic matter, Aust. J. Soil Res., 30, 195-207, 1992.

Watanabe, K. and Kuwae, T.: How organic carbon derived from multiple sources contributes to carbon sequestration processes in a shallow coastal system?, Glob. Change Biol., 21, 2612-2623, 2015. 